\section{Mediul de învățare în aer liber}

Outdoor learning environment

Iftimia Brîndușa, doctorandă, UPS

„Ion Creangă”

ORCID: 0000-0002-0017-863X

Stela Gînju, doctor în biologie,

conferențiar universitar, Facultatea de

Științe ale Educației și Informatică,

Catedra de Pedagogie Preșcolară, Educație

Fizică și Dans,

UPS ,Ion Creangă”

ORCID: 0000-0002-0673-2099

\section{CZU 372.32}

\section{Rezumat}

Mediul de învățare în aer liber reprezintă nu o alternativă a învăţării din grădiniță, ci o aprofundare, o personalizare a procesului instructiv-educativ; acest mediu, organizat corespunzător, devine o sursă de cunoaștere, un spațiu stimulativ, confortabil, creativ, original, favorabil pentru dezvoltarea cognitivă și socioemoțională a copilului. În contextul educaţional actual, dominat de provocări și schimbări frecvente, este nevoie să ne întoarcem la natură și să conectăm copiii cu ea prin diverse activități. În felul acesta, le vom asigura copiilor o sănătate mai bună, gestionarea corectă a emoțiilor, autonomie, stimă de sine, formarea unor abilități de viață care să îi ajute să se adapteze în societate.
Cuvinte-cheie: mediu de învățare în aer liber, dezvoltare cognitivă, educație experențială.

\section{Abstract}

The outdoor learning environment is not an alternative to learning in kindergarten, but a deepening, a personalization of the instructive-educational process; this environment, properly organized, becomes a source of knowledge, a stimulating, comfortable, creative, original space, conducive to the cognitive and socioemotional development of the child. In the current educational context, dominated by frequent challenges and changes, we need to return to nature and connect children with it through various activities. We will ensure the children a better health, the correct management of emotions, autonomy, selfesteem, the formation of life skills that will help them to adapt to society.

Keywords: outdoor learning environment, cognitive development, experiential education.

Învățarea nu înseamnă doar dobândirea de cunoștințe și abilități, ci formarea unor capacități și disponibilități de a fi eficient și productiv în diverse situații de viață. Experiența actuală ne demonstrează că există un decalaj între educație și viață, între ceea ce societatea solicită si educația oferă. 
Organizarea procesului instructiveducativ într-un cadru bine structurat, săli de grupă, laboratoare și folosirea spațiilor din jurul grădinițelor, ca spații exclusive de joc și relaxare, nu este suficientă pentru formarea unei personalităţi armonioase, capabile să se descurce în societatea tot mai dinamică în care trăim. Astfel spus, este nevoie de mai mult decât de o sală de grupă și de un educator. În sala de grupă, copiii învață, manipulează obiecte şi substitute ale acestora (de exemplu, ilustrații), utilizează resurse digitale: audio, video, dar resursele sunt limitate.

În afara sălii de grupă, este o lume dinamică, vie, plină de culoare și miros, de mister și bogăție. Întrebarea firească este cum conectăm viața cu învățarea?

Învăţarea în mediul natural are origini ancestrale. Din cele mai vechi timpuri, oamenii au învățat în aer liber, în mijlocul naturii, iar evoluția noastră ca specie s-a produs în acest mod. Modelul de învățare în aer liber este unul vechi.

În Grecia Antică, idealul educațional (Kalokagatia) se realiza prin obținerea armoniei omului cu natura și mediul exterior. Aristotel, studentul lui Platon și profesorul lui Alexandru cel Mare, preda cunoștințele în aer liber, școala lui fiind organizată în trei peșteri, cu vegetație luxuriantă, cu cărări întortocheate, pâraie reci, care izvorau din munţi.

„Creştinismul s-a adresat oamenilor simpli, explicarea vieţii şi a naturii fiind fundamentală ca metodă de la care se pornea în schimbarea mentalităţilor păgâne şi idolatre. De aceea pildele lui Iisus s-au referit la natură şi la mediul înconjurător, pentru ca oamenii cărora se adresa să aibă un punct de reper solid în înţelegerea relaţiilor dintre ei, iar mai târziu, în scopul înalt al apropierii de Dumnezeu [8].

J.A. Comenius (1592-1670) scria că învățământul trebuie să se desfășoare după modelul naturii, într-un mediu care să sprijine învățarea conştientă și activă, plăcut, stimulativ. ,[...] natura începe întotdeauna cu ce este curat;/natura pregătește materia pentru a primi forma;/natura trece treptat de la cele mai ușoare la cele mai grele" [4].

Acesta considera omul ca fiind parte din natură, iar procesul instructiv- educativ se desfăşoară după legile naturii; prin prisma principiului conformităţii cu natura, J.A. Comenius menţiona: „să urmărim natura, s-o învăţăm. Aşa cum natura, spre a-şi realiza opera ei, aşteaptă un timp potrivit, tot aşa şi noi educăm omul la timpul potrivit, în primăvara vieţii” [Idem, p. 4].

Jean-Jacques Rousseau (1712-1778) a exprimat foarte concis ideea că natura reprezintă un model de învățare pentru copii; acesta consideră că între 2 și 12 ani se produce o educație a simțurilor prin contactul nemijlocit cu natura, vorbește despre „marea carte a naturii” ca sursă inepuizabilă de cunoaștere. Din punctul său de vedere, educaţia trebuie să se facă în mediul natural, copilul fiind liber, doar supravegheat de un 
preceptor [7].

Ideile lui Rousseau au fost transpuse şi în opera lui Dimitrie Cantemir (1673-1723) „Divanul sau gâlceava înţeleptului cu lumea”, în care autorul menţionează că scopul educaţiei este acela de a pregăti oameni înţelepţi, care să aspire la liniştea sufletească, pe calea cunoaşterii naturii [1].

Termenul grădiniță a fost elaborat de savantul F.W. Frobel (1782-1852), care consideră că, pentru copiii mici, mediul de învățare cel mai potrivit este, grădina de copii” (Kindergarten). „Copilul trebuie inițiat de timpuriu în cunoașterea naturii, nu numai în ceea ce privește formele sale de manifestare, ci în maniera în care spiritul divin trăiește în natură și planează deasupra ei. Trebuie ca părinții și institutorii să nu lase să treacă o săptămână fără să ducă în natură pe școlari, determinându-i să observe și să admire bogățiile variate pe care le etalează în fața ochilor noștri natura în fiecare anotimp [5].

\section{Maria Montessori}

(1870-1952) descoperă și explorează o nouă pedagogie, „,pedagogia științifică”, și propune ca mediul de învățare să fie dotat cu materiale didactice corespunzătoare fiecărui simț în parte, care să încurajeze experimentele și descoperirile pozitive. În viziunea sa, mediul de învăţare trebuie să fie stimulativ, copilul să fie liber și să învețe în mod spontan, fără să depună un efort mare pentru a învăța.

Dezvoltarea unui mediu de învățare stimulativ, prin joc, aparţine savantului E.
Claparede (1873-1940), care ține cont, în organizarea învățării, de nevoile de dezvoltare ale copiilor, susținând ideea necesităţii școlii „laborator”, și nu a școlii „auditor”, ceea ce sugerează o participare plenară a copilului, prin joc și experimentare [3].

Analizând concepțiile pedagogilor referitoare la modul în care se realizează educația, remarcăm că, în secolul pe care îl parcurgem, educația s-a retras în săli cu lumină artificială, iar standardele se referă la cât de multe informații acumulează copilul, mai puțin la cum își poate aplica competențele în contexte variate. Așadar, completarea educației în sala de grupă cu cea în aer liber nu este un act de curaj, ci un exemplu de bună practică.

Învăţarea în aer liber reprezintă un tip de educație care câștigă tot mai multă popularitate și se implementează în sistemele de învățământ din întreaga lume, respectând caracteristicile fiecărei țări (culturale, sociale, economice). De-a lungul timpului, acest concept a cuprins noțiuni ca: „educație pentru natură”, „forest school”, „educație în afara clasei”, „educație outdoor”, „educație experențială” sau ,educație ecologică”. În unele țări, educația în aer liber este sinonimă cu învățarea în aer liber și presupune conceptul de „educație pentru natură”. În contextul actual, al schimbărilor sociale, învățarea în aer liber devine o necesitate și practica pedagogică va demonstra, pe măsură ce se va folosi mai mult spațiul din afara 
sălilor de grupă, eficiența în dezvoltarea cognitivă, socială și afectivă a preșcolarilor.

Completarea activităților din sala de grupă cu activități de învățare în aer liber reprezintă o soluție agreată de toți factorii implicați în procesul educaţional: profesori, părinți, copii; este o formulă de învățare eficientă din punctul de vedere al conexiunii directe cu natura, al menținerii sănătății copiilor, al conexiunii sociale, al relațiilor umane. Pentru preșcolari și școlari, acest tip de învățare constituie o completare a învățării tradiţionale, o formă valoroasă de explorare a realității.

La nivel mondial, există un interes deosebit pentru înființarea unor centre de învățare în aer liber; astfel, în unele țări latino-americane au fost recunoscute și acreditate grădinițe care folosesc această modalitate de realizare a activităţilor instructiv-educative, în urma rezultatelor foarte bune obținute de copii. Natura, ca parte integrantă a firii umane, nu poate să lipsească din dezvoltarea copiilor; în mijlocul ei și cu resursele pe care le pune la dispoziție, copilul evoluează, respectându-i-se ritmul propriu de dezvoltare şi încurajându-l să devină autonom, responsabil și implicat în propria sa devenire [9].

Danemarca este cea mai veche tară care a implementat conceptul de ,învățare în aer liber", spaţiul interior se prelungește în exteriorul școlii, natura oferind oportunități deosebite de stimulare senzorială, experimentare, dobândire de noi cunoștințe nemijlocit, de dezvoltare a relațiilor interpersonale.

Unul dintre modelele valoroase de învățare în aer liber, experimentat în Marea Britanie, este „Forest school” - „Școala din pădure": copiii, periodic, vizitează pădurea, cu scopul de a-și dezvolta abilități practice și sociale, abilități personale - gândire critică și rezolvare de probleme. În mediul ofertant al pădurii, învățarea acoperă teme integrative actuale: poluare, mediu, specii de plante, faună, defrișare etc. Valoarea acestui tip de învățare se referă mai ales la aspectul practicaplicativ, de facilitare a dezvoltării cognitive și a cooperării ca urmare a muncii desfășurate în echipă. Astfel, se încurajează curiozitatea, explorarea prin toate simțurile, motricitatea generală; copiii sunt mai relaxați, au atenția concentrată, iar cei care au probleme de învățare, probleme de comportament sau deficit de atenție sunt mult mai ușor integrați.

Cum ar trebui să arate mediul de învățare în aer liber în instituțiile de educație timpurie? Cum ar trebui organizat, pentru a satisface nevoia de cunoaștere și de socializare a copiilor? Iată câteva exemple: o parcelă de pământ în care să se poată planta/grădinări; o parcelă cu nisip în care să se poată construi utilizând materiale diverse; panouri cu diverse jocuri care dezvoltă abilitățile practice ale preșcolarilor: închidere/deschidere;

încuietori/decorat/curățat/etc.;

trasee senzoriale; spaţii amenajate pentru îngrijirea păsărilor; instrumente de 
Revista de ştiinţe socioumane $\mathcal{T}_{r .3}$ (46) 2020

măsurare a timpului și de observare a schimbărilor din natură; o zonă de relaxare, cu măsuțe și scaune, unde să se poată desena, colora etc.; bănci, pe care copiii să se poată odihni.

Copiii trebuie să învețe să aibă grijă de mediul exterior: să semene, să planteze, să recolteze, să adune frunze, pietricele, să aibă grijă de plante, să folosească un furtun, să plivească, să observe natura (germinarea, mormolocii, păsările etc.) [6].

Cercetările interdisciplinare realizate la nivel mondial au evidenţiat numeroase beneficii ale învățării în aer liber: îmbogățirea vocabularului cu cuvinte și structuri noi, ca urmare a diversității termenilor pe care copiii îi întâlnesc; dezvoltarea abilităţilor cognitive; gândire divergentă, ce conduce la rezolvare de probleme în mai multe domenii; imaginație creativă și memorie fidelă; capacitatea de aplicare în practică a conceptelor însușite afară; o participare activă, angajare a întregului corp, implicare a tuturor simţurilor, angajament, atitudine faţă de învățare; concentrare mai bună a atenţiei, autocontrol, stare de bine; o bună coordonare motrică, reducerea obezității și a consecinţelor bolilor transmisibile; reducerea anxietăţii.

În cadrul unui studiu comandat de The Wildlife Trusts și realizat la Institutul de Educație al UCL (University College London) despre beneficiile activităților desfășurate în aer liber și apărut în The Telegraph (UK), se precizează beneficiile profunde și diverse ale contactului regulat $\mathrm{cu}$ natura. Contactul $\mathrm{cu}$ mediul sălbatic îmbunătățește starea de bine a copiilor, le creşte motivația și încrederea [10].

Un aspect important al învățării în aer liber este concentrarea pe experiențele relevante la care copilul participă, și nu pe dotarea spaţiilor cu echipamente sofisticate; natura oferă o multitudine de oportunități și valorificarea eficientă a acestor oportunități depinde de creativitatea cadrului didactic.

Rolul mediului de învățare în aer liber este acela de a personaliza procesul educaţional și de a-i oferi o notă de libertate și de originalitate. Desigur, prin libertate nu se înțelege lipsa de reguli și de norme, ci se înţelege mai mult libertatea de a alege dintrun set de metode metodele adecvate unui copil sau unui grup.

Pentru realizarea obiectivelor propuse, este importantă diversificarea formelor de organizare a întregii activităţi si creșterea ponderii altor tipuri de forme de organizare a procesului de tip instructiveducativ, precum sunt: activitățile practice, observări, drumeții, experimente etc.

În organizarea întregului mediu de învățare în afara clasei, se are întotdeauna în vedere îmbinarea cât mai optimă, potrivit tuturor obiectivelor urmărite, a trei tipuri principale de forme de activitate [2]:

- activitatea cu întreg colectivul de copii;

- activitatea în mai multe grupe de copii;

- instruirea în pereche/cuplu;

- activitatea individuală.

Fiecare copil are dreptul să îi fie respectat, dreptul la propriul mod de 
Revista de ştiinţe socioumane $\mathcal{T}_{\text {r.3 }}$ (46) 2020

dezvoltare. De aceea, grădinița trebuie să creeze condițiile cele mai bune de educare și de formare a preșcolarilor, oferind ocazia manifestării individualității și creativității acestora.

\section{Bibliografie}

1. CANTEMIR, D. Divanul sau gîlceava înţeleptului cu lumea. Bucureşti: Editura Minerva, 1969.

2. CERGHIT, I. Sisteme de instruire alternative și complementare. Structuri, stiluri și strategii. București: Editura Aramis, 2002.

3. CLAPAREDE,

E. Educația funcțională. București: Editura Didactică și Pedagogică, $\quad 1973,173$ p. $\quad$ ISBN 1763559167.

4. COMENIUS, J.A. Didactica Magna. București: Editura Didactică și pedagogică, 1970.

5. FROBEL, F. L`education de $\mathrm{l}$ homme. Paris: Editions Ract\&C, 1961.

6. POUSSIN, CH. Pedagogia Montessori explicată părinţilor. Iași: Editura Gama, 2017.

7. ROUSSEAU, J.J. Emil sau despre educaţie. Dimitrie Todoran. [trad.] Dimitrie Todoran. București: Editura Didactică și Pedagogică, 1973. ISBN 821.133.1.31.

8. UNGUREANU, G., Conceptul antic și tradițional în evoluția educației. În: Revista ART-EMIS ACADEMY, 2012.
9. $\underline{\text { https://creeracord.com/tag/invatarea- }}$ individualizata/accesat

(vizitat la 31.08.2020).

10. https://www.telegraph.co.uk/news/2019/11 /06/learning-outside-just-one-lesson-weekboosts-learning-behaviour/accesat

(vizitatla 31.08.2020).

\section{Восприятие и оценка голода в}

Бессарабии 1946-1947 годов глазами современных гагаузов

(проживающих в Буджаке)

The perception and assesment of the 19461947 Famine in Bessarabia through the eyes of contemporary Gagauzes

(living in Budjak)

Jerzy Hatłas, doctor în istorie, magistru în arheologie, membru al Comisiei Balcanistice a Academiei de Ştiințe din Polonia, Universitatea „Adam Mickiewicz", Biblioteca Universitară, Poznan, Polonia ORCID: 0000-0002-1768-6243 CZU 94(478)

\section{Резюме}

С 1946 по 1947 год в Бессарабии разразился голод, унёсший множество жертв. Причины голода, как в научной литературе, так и со стороны жителей региона, трактуются по-разному. За 